УДК635.646

\title{
СЕЛЕКЦИЯ СОРТОВ БАКЛАЖАН ДЛЯ ОТКРЫТОГО ГРУНТА ЗАПАДНОЙ СИБИРИ
}

\author{
Свидовская Наталья Николаевна \\ c.H.c. \\ Кашнова Елена Васильевна \\ K.C-X.H, В.H.c. \\ Западно-Сибирская овощная опытная станция - \\ филиал ФГБНУ ФНЦО
}

Аннотация: В статье представлен результат селекционной работы на Западно-Сибирской овощной опытной станции по селекции баклажан.

Приведены характеристики созданных сортов Вера, Диалог, Внучок, Кубышка, Ларец, Сундучок. Представлены данные по продолжительности вегетационного периода, урожайности и качеству плодов.

Ключевые слова: баклажан, селекция, урожайность, биохимические показатели, сорт.

\section{BREEDING OF EGGPLANT VARIETIES FOR OPEN SOIL IN WESTERN SIBERIA}

\section{Svidovskaya Natalia Nikolaevna Kashnova Elena Vasilievna}

\begin{abstract}
The article presents the result of selection work at the West Siberian Vegetable Experimental Station for the selection of eggplant.

The characteristics of the created varieties Vera, Dialogue, Vnuchok, Kubyshka, Larets, and Sunduchok are given. The data on the duration of the growing season, yield and quality of fruits are presented.
\end{abstract}

Key words: eggplant, selection, yield, biochemical parameters, variety.

\section{Введение}

Овощи и картофель необходимы для питания человека. Они не только содержат нужные организму белки, жиры, углеводы, минеральные соли, органические кислоты, микроэлементы, но и являются исходным материалом 
для образования в организме веществ, без которых нормальное развитие и жизнь человека невозможна.

Баклажан - одна из пасленовых овощных культур, широко распространенная во всем мире. Посевные площади исчисляются гектарами, где климатические условия позволяют еe выращивать, а урожайность достигает 30-35 т/га. Основными производителями баклажан являются страны Центральной и ЮгоВосточной Азии [1]. На Востоке баклажан считают «овощем долголетия».

Баклажан - хороший диетический продукт, калорийность которого выше, чем у томата и огурца. Употребление плодов в пищу значительно уменьшает содержание холестерина в крови [2]. Включение баклажана в рацион питания пожилых людей особенно полезно, так как широкий набор минеральных веществ, прежде всего калия, нормализует сердечную деятельность, водно солевой и жировой баланс.

Плоды маринуют, сушат, солят целыми или фаршированными с различными овощами. Соленые баклажаны на юге заменяют грибы [3].

На Западно - Сибирской овощной опытной станции до 1998 года не было создано ни одного сорта баклажана. Перед лабораторией селекции и семеноводства пасленовых культур была поставлена задача, создать и передать в ГСИ раннеспелый сорт баклажан с урожайностью 13-15 т/га, с высокими товарными качествами для возделывания в условиях Западной Сибири.

Были определены основные задачи селекции: высокая урожайность, товарность, качество продукции, устойчивость культуры к температурным изменениям и устойчивость к поражению болезням и вредителям.

\section{Условия, материалы и методы исследований}

Исследования проводили на полях Западно - Сибирской овощной опытной станции филиала ФГБНУ ФНЦО (1990 - 2020 гг.) в условиях открытого грунта.

В качестве исходного материала была использована коллекция образцов различного эколого-географического происхождения, полученная из ВНИИ растениеводства им. Вавилова, а также местные образцы и гибриды.

При проведении исследований использовали общепринятые методики $[4,5,6]$. Все образцы оценивались на стабильность урожайности, высокие товарные качества, относительную устойчивость к черной бактериальной пятнистости на естественном фоне заражения.

Селекционную работу вели с помощью индивидуального и массового отбора, применяя методы аналитической и синтетической селекции. Вели отбор на комплекс хозяйственно ценных признаков, а именно: урожайность, 
выравненность плода, скороспелость. Большое внимание уделялось биохимическим показателям.

В дальнейшем проводили оценку отобранных образцов в контрольном питомнике. Лучшие из перспективных образцов изучали в питомнике конкурсного испытания в сравнении со стандартными сортами.

Результаты исследований. В результате селекционной работы на Западно-Сибирской овощной опытной станции были созданы и внесены в Государственный реестр селекционных достижений конкурентоспособные сорта баклажан с разной окраской плода и мякоти, с различной формой плода, способные давать стабильный урожай в условиях открытого грунта Западной Сибири.

Сорт Вера - сорт раннеспелый, от всходов до первого сбора 110-115 суток, куст компактный, средняя высота растения 75 см. Плод удлиненно грушевидной формы, не касающийся почвы, в технической спелости ярко фиолетовый с глянцевой поверхностью. Мякоть плода белая, плотная без пустот. Масса плода (средняя) 179 г. Товарная урожайность в среднем составила 170-190 ц/га.

Сорт Диалог - сорт среднеспелый, от всходов до технической спелости 118-123 суток.

Средняя высота растения 62 см. Куст раскидистый, средняя ширина 70 см. Плоды грушевидной формы, первые касаются почвы, малиново - фиолетового цвета с глянцевой поверхностью. Средняя масса плода 163г. Товарная урожайность составляет от 15,0-21,6 т/га.

Сорт Внучок - сорт среднеспелый, от всходов до технической спелости 118-126 суток. Высота растения в среднем 69 см. куст полураскидистый, облиственность средняя. Плоды слаборебристые, укорочено - грушевидной формы, фиолетово - малинового цвета, поверхность блестящая, мякоть белая, средней плотности. Первые плоды касаются почвы. Масса плода в среднем 129 г, отдельные плоды достигают до 400 грамм. Товарная урожайность сорта составляет 18,7 т/га.

Сорт Кубышка - сорт среднеспелый, от всходов до технической спелости 118-126 суток. Высота растений в среднем 77 см (от 58 до 92 см). Куст штамбовый, полураскидистый, облиственность средняя. Лист яйцевиднозаостренный, среднего размера, зеленого цвета. Чашечка темно фиолетового цвета, со слабыми шипами. Плоды укорочено - грушевидной формы, фиолетового цвета, поверхность глянцевая, мякоть светло - зеленая, 
средней плотности. Первые плоды касаются почвы. Средняя масса плода 137 г (отдельные плоды достигают до 450 г). Товарная урожайность в условиях открытого грунта составила 15,6 т/га.

Сорт Ларец - сорт среднеспелый, период от всходов до технической спелости 128-136 суток, до биологической 153-162. Высота растений 52 см (от 46 до 58 см). Куст - штамбовый, полураскидистый, облиственность средняя. Лист яйцевидный заостренный, среднего размера, зеленого цвета с фиолетовыми прожилками. Чашечка зеленого цвета со слабыми шипами. Плоды удлиненно-грушевидной формы, окраска плодов в технической спелости фиолетового цвета со слабыми полосами, в биологической - серая, поверхность глянцевая, мякоть белая, средней плотности, без горечи. Плоды крупные средняя масса 134 г (от 128 до 159 г), отдельные плоды достигают 350 г. Товарная урожайность сорта Ларец составляет 13,5-22,6 т/га.

Сорт Сундучок - среднеспелый, от всходов до технической спелости $132-144$ суток.

Высота растения в среднем 66 см (от 60 до 77 см.). Куст - штамбовый, полураскидистый, облиственность средняя. Лист яйцевиднозаостренный, среднего размера, зеленого цвета с зелено-фиолетовыми прожилками. Чашечка зеленого цвета, со слабыми шипами. Плоды грушевидной формы, окраска плодов в технической спелости фиолетового цвета, слаборебристые, в биологической - серая, поверхность матовая, мякоть белая, средней плотности, без горечи. Плоды крупные, средняя масса 185 г (от 169 до 208 г), отдельные плоды достигают веса 450 г. Товарная урожайность в условиях открытого грунта у сорта Сундучок составила 27,5 т/га.

Все созданные на станции сорта баклажан имеют высокие биохимические показатели (табл. 1).

Таблица 1

Биохимическая характеристика сортов баклажан

\begin{tabular}{|l|c|c|c|}
\hline \multirow{2}{*}{\multicolumn{1}{|c|}{ Сорта }} & \multicolumn{3}{|c|}{ Содержание } \\
\cline { 2 - 4 } & Сухое вещество, \% & Общий сахар, \% & Витамин С, мг\% \\
\hline Вера, ст & 8,22 & 2,24 & 6,98 \\
\hline Диалог & 8,57 & 2,60 & 6,75 \\
\hline Внучок & 8,03 & 3,05 & 7,05 \\
\hline Кубышка & 7,67 & 2,25 & 5,68 \\
\hline Ларец & 7,52 & 2,27 & 7,19 \\
\hline Сундучок & 7,52 & 2,27 & 7,18 \\
\hline
\end{tabular}




\section{Заключение}

В процессе селекционной работы создана группа сортов баклажан, не накапливающая горечи в плодах, обладающая широким набором хозяйственно ценных признаков, которые рекомендуются для возделывания в условиях открытого грунта Западной Сибири.

\section{Список литературы}

1. Гиш, Р.А. Баклажан. Биология, сорта, технология возделывания/ Р.А. Гиш.// Краснодар: КубГАУ, 1999. С. 11.

2. Авдеев Ю.И. Теоретические и прикладные исследования по овощным культурам /Ю. И. Авдеев // Астрахань 2004г.- С.260

3. Гераськина Н.В./Новый сорт баклажана Меч самурая// Гераськина Н.В. Картофель и овощи.№11, 2019г. - С. 37

4. Методика Государственного сортоиспытания сельскохозяйственных культур. М., 1976. -182 с.

5. Доспехов Б.А. Методика полевого опыта. /Б.А. Доспехов. - М., 1986. $-351 \mathrm{c}$.

6. Методические указания по селекции сортов и гибридов перца и баклажана для открытого и защищенного грунта. М., - 1977. -25 с.

(C) Н.Н. Свидовская, Е.В. Кашнова, 2020 